INSIGHTS INTO REGIONAL DEVELOPMENT

ISSN 2669-0195 (online) http://jssidoi.org/IRD/

2021 Volume 3 Number 1 (March)

http://doi.org/10.9770/IRD.2021.3.1(1)

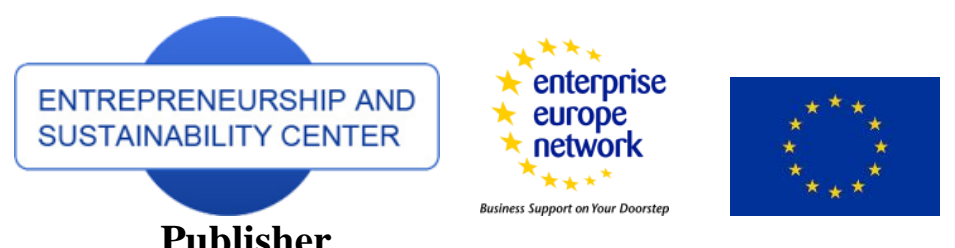

http://jssidoi.org/esc/home

\title{
SOCIAL JUSTICE AND SUSTAINABLE REGIONAL DEVELOPMENT: REFLECTIONS ON DISCOURSE AND PRACTICE IN PUBLIC POLICIES AND PUBLIC BUDGET
}

\author{
Vitor Vieira Vasconcelos \\ Universidade Federal do ABC, Alameda da Universidade, s/n, São Bernardo do Campo, São Paulo 09606-045, Brazil \\ E-mail:vitor.v.v@gmail.com
}

Received 15 June 2020; accepted 10 December 2020; published 30 March 2021

\begin{abstract}
Considerations are presented on discourses and practices of public policies and public budget, regarding territorial development. The considerations are based on the author's experience in government institutions, at state and national level, in the executive and legislative powers in Brazil. This experience is compared to theoretical and applied studies on sustainable regional development, including agrarian reform, small-scale farming, ecological-economic zoning, transport infrastructure, city network hierarchies, and budgetary policies. The discussion shows how, behind discourses of regional development, there may be strategies for maintaining political power which may not always be the most appropriate for improving people's quality of life.
\end{abstract}

Keywords: regional development; public policies; public budget; sustainable development; politics

Reference to this article should be made as follows: Vasconcelos, V.V. 2020. Social justice and sustainable regional development: reflections on discourse and practice in public policies and public budget. Insights into Regional Development, 3(1), 10-28. https://doi.org/10.9770/IRD.2021.3.1(1)

JEL Classifications: Q01, Q58, R5

Additional disciplines: law; political sciences; sociology; ecology and environment

\section{Introduction}

In the Brazilian Constitution, there are several principles to guide territorial development. Such principles can be observed in Articles 3 and 170 of the Constitution:

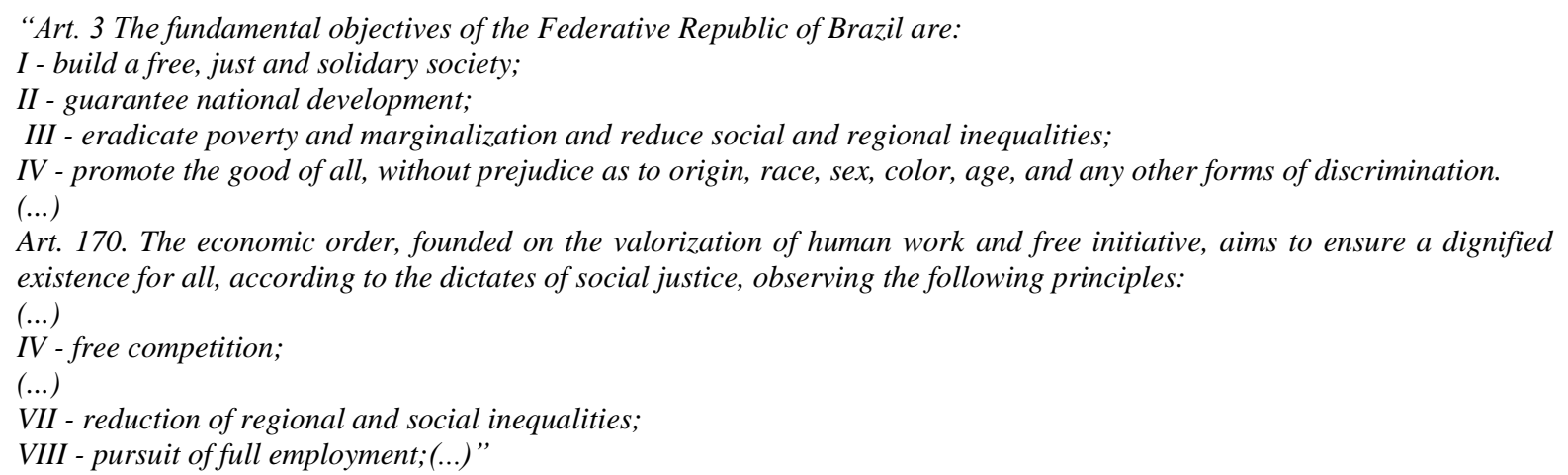


INSIGHTS INTO REGIONAL DEVELOPMENT

ISSN 2669-0195 (online) http://jssidoi.org/jesi/

2021 Volume 3 Number 1 (March)

http://doi.org/10.9770/IRD.2021.3.1(1)

Make your research more visible, join the Twitter account of INSIGHTS INTO REGIONAL DEVELOPMENT:

@IntoInsights

It is interesting to interpret these concepts not only from a normative point of view, but as they were written based on influences of social groups that were not totally in agreement with each other. The construction of the constitutional text reflects the electoral bases, the economic sectors that finance political campaigns, and the strategies of maintaining power of political representatives. Thus, it can be said that the constitutional principles present a quasi-coherent quasi-dialogue (Potseluev, 2010; Wodak and Rheindorf, 2017). This article intended to explore this perspective of discourse construction, without relegating conflicts or even the distance between these discourses, and the effective practice of public policies.

The purpose of this text is not to present or discuss a theoretical overview of regional development issues and relations between metropolises, medium-sized cities, and rural areas, and much less to present conclusions about these theories. For a reader interested in entering into the theoretical or applied aspects of the dynamics of concentration or regionalization of development, and its relationship with public policies focusing on the Brazilian context, the studies by Lemos (2009), Galvanese (2018), Rocha et al., 2018; Cardoso et al., 2018; Muniz et al., 2018; Monni et al., 2018 are recommended.

More modestly, this article presents reflections based on the author's personal experience in his activities in public sector activities related to regional development, in the executive and legislative powers. It begins by discussing experiences in the area of rural extension and environmental regularization of small farmers and agrarian reform settlers. Next, it covers the applied cases of territorial development plans, in the areas of transport and ecologicaleconomic zoning, and how these experiences led to reflections on the regional development of medium-sized cities or depressed areas. Then, experiences related to the activities of the legislative power and their influence on budget planning and implementation are discussed. These experiences were permeated by academic studies in the areas of geography, law, economics, and environmental sciences, which led to polemical questions, even if not always with satisfactory answers.

\section{Reflections on agrarian reform settlements and small-scale farming}

In 2006, fresh out of university and research institutes when I started my job as a technician at the National Institute of Colonization and Agrarian Reform-INCRA - my older colleagues at this institution warned me about the emotional burden that is involved with rural extension work with the poorest communities in the interior of Brazil. As warned, the emotional shock was striking. Especially in the first contact I had with the camped and settled farmers, when faced with their situation of poverty, living in canvas tents, with difficulties in accessing water or public services.

The government programs foresaw the implementation of several actions for the structuring of the settlements, such as construction of houses and roads, drilling of wells, environmental regularization, land georeferencing, implementation of infrastructure for collective agro-industries, and credit for production. Such programs instilled dreams and hopes in the newly settled, however, the lack of officers in INCRA, as well as the lack or blocking of budget allocation, meant that such measures were implemented very slowly, taking more than 20 years for a large part of the settlements. This situation caused real discomfort among public officers, who in the exercise of their function, when explaining government programs, realized how they were generating expectations about something that would be implemented with great difficulty.

The low living conditions of the settlers and their stance of pleading for government assistance was a highly contrasting reality when compared to the scenario of cultural appreciation of rural people broadcasted at the 
INSIGHTS INTO REGIONAL DEVELOPMENT

ISSN 2669-0195 (online) http://jssidoi.org/jesi/

2021 Volume 3 Number 1 (March)

http://doi.org/10.9770/IRD.2021.3.1(1)

Make your research more visible, join the Twitter account of INSIGHTS INTO REGIONAL DEVELOPMENT:

@IntoInsights

universities by professors who defended family farming. This is not to say that it was not possible to perceive the country culture, especially in the older members of the rural communities. However, with the arrival of electricity, the time dedicated to experiencing and transmitting culture was practically all filled with television and radio, meaning that the younger generation kept little of their grandparents' culture. Additionally, in a society in which access to human rights and quality of life depends on the level of income, urban culture was identified with wealth, thus leading to a lower appreciation of local culture (as well as observed by Ferreira, 2006).

The difficulties of life in the countryside go beyond the cultural sphere, and we cannot say that they were restricted to the inhabitants of the rural area, as expressed in the following statement by geographer Milton Santos:

\footnotetext{
"I'm not a fan of the countryside. I think it is a horrible business to condemn the person to live in the country. [...] The key is people, and their needs and rights, and not where they are. [...]. From the point of view of the people, it is perverse to condemn a young person to a worse education, less careful medical care and limited information and, consequently, limited political participation. Because information is politics... "(SANTOS, 2000, p. 57-58).
}

From this contact with family farming, it was possible for me to distinguish two very different "worlds". Small horticulturists in green belts supplying large urban centers had viable businesses with greater productive efficiency. However, in areas far from green belts, families on small farms sought to live predominantly from livestock and generally made losses in their accounts, maintaining themselves through government social assistance in the form of family care allowance, rural retirement, and other complementary public policies. Corroborating this view, Alves (2012) shows that based on data from Brazilian agricultural censuses, agricultural properties focussed on livestock, especially family farms, tend to have a loss in their net income, with the opposite occurring in properties focussed on agriculture. This situation becomes more worrying when considering that in 2006, 59 million hectares were used for grazing for family farming, and only 22 million hectares were used for agriculture (IBGE, 2006). A regionalized version of this polarization appears when comparing family farmers in the South and Southeast regions of Brazil (more integrated with urban markets) in relation to family farmers in other regions of the country (Kageyama, 2003). According to Alves (2012), it is a challenge for Brazil to discover how to treat the 2.9 million poor rural establishments with negative net income (out of a national total of 4.4 million rural establishments).

In these areas far from urban centers, it became notorious how various projects started with public resources and were later abandoned, such as flour factories, candy factories, fish farms, and seedling nurseries. Drilled wells were abandoned due to lack of maintenance, and materials destined for the fencing of springs and conservation reserves were left to rot. Such failures in the application of public funds were never officially accounted for, as the government was not interested in publicizing its flaws, nor did it want to upset groups of voters who had benefited from the investments.

According to my personal observation as well as the opinion of other more experienced extension technicians, the main cause for these failures in development projects, as well as the general obstacle to rural development and improved quality of life in small family farms in these depressed areas, was due to the limits of managerial capacity (productive and domestic) of the families, and not the need for deep technical knowledge or investment capacity. Habits such as covering cisterns, adhering to hygiene procedures related to food preparation and home maintenance, assessing when it was necessary to go to the doctor, fertilizing and adding limestone powder to the soil, stopping burning the pasture and instead implementing management of pasture rotation and silage, and planting in level ranges perpendicular to the slopes are some examples of relatively simple practices which rural extension workers reported a lot of difficulty in being assimilated, mainly by family farmers who had low access to formal education. 
INSIGHTS INTO REGIONAL DEVELOPMENT

ISSN 2669-0195 (online) http://jssidoi.org/jesi/

2021 Volume 3 Number 1 (March)

http://doi.org/10.9770/IRD.2021.3.1(1)

Make your research more visible, join the Twitter account of INSIGHTS INTO REGIONAL DEVELOPMENT:

@IntoInsights

The differentiation between these two "worlds" of family farming was also felt in the evaluation of financing granted under the National Program for Strengthening Family Agriculture - PRONAF. Despite the generally positive results in relation to the compliance with PRONAF, widely disseminated by the government (Belik, 2000), it is necessary to understand that this public policy instrument cannot be directly compared to other bank loans, because in several of the PRONAF modalities, there were subsidies and debt relief justified by social assistance (Guanzirol, 2006). There was, markedly, a big difference between the percentage of default on loans in the areas surrounding urban centers (good payers), and in the most marginalized interior areas in which many projects failed due to difficulty in integrating into the market, as also verified by Guanzirol (2006). In addition, family farmers in areas with better economic dynamics gained more access to PRONAF, in terms of number of contracts and total volume of resources, while farmers in the most depressed areas found it more difficult to organize the process needed to access the resource, as indicated in the studies by Aquino and Schneider (2010). Studies that have closely followed the use of PRONAF in the properties (Ferrari; Abraão, 2008) have shown that family farmers normally invest a large part of the money obtained in other unrelated activities, such as paying local debts, health treatments, expanding housing for sheltering newlywed siblings, and buying cars; then, to repay the PRONAF installments, the farmer would have to work much harder than if he had invested the money properly in productive activities. The formulation of the discourse of the social movements in defense of agrarian reform and family farming often included some fundamentals regarding the conservation of the environment, which are worth presenting:

\footnotetext{
- The environmental impact of family farmers occurs as they need to produce in order to prevent hunger.

- With the improvement of rural productivity, the farmer needs to deforest less areas for production.

- Traditional knowledge has developed sustainable ways of working with nature.

- The countryman wants to stay in the countryside.
}

On the other hand, what was perceived in the experience of professionals from government agencies of rural extension or environmental regularization, is that social and economic development in previously depressed areas increases the rate of deforestation and environmental degradation, while farmers abandon the traditional methods in favor of modern production models. I was able to perceive this modernization transition specifically when accompanying the Veredeiros (traditional farmers in wetland ecosystems called veredas) in the northwest of Minas Gerais State, according to the study by Vasconcelos and Seingyai (2013). Also relevant is the observation by Gazolla and Schneider (2005) and Toledo (2009) that access to PRONAF in general has marked the abandonment of traditional techniques in favor of mechanized cultivation with a high application of pesticides and other modern agricultural inputs.

In another aspect, INCRA technicians also observed the constant pace of abandonment of land allotments by land reform settlers returning to the cities. Many of these settlers, either from urban peripheries, or hired rural workers without their own land, had joined social organizations for rural land in the hope of returning to the life of rural production which their parents and grandparents led. However, shortly after settling, they became frustrated in face of the difficulties of life as family farmers, informally selling their lots, even though such sale was, and still is legally prohibited (Abramovay, 2005; Vasconcelos, 2011).

\section{Territorial development plans}

After my time at INCRA, I worked at the Technological Center Foundation of Minas Gerais State-CETECMG - in 2009, with the preparation and analysis of planning studies for territorial development. Then from 2009 to 2010 I worked at the Brazilian Institute of Environment and Renewable Natural Resources-IBAMA—, in 
INSIGHTS INTO REGIONAL DEVELOPMENT

ISSN 2669-0195 (online) http://jssidoi.org/jesi/

2021 Volume 3 Number 1 (March)

http://doi.org/10.9770/IRD.2021.3.1(1)

Make your research more visible, join the Twitter account of INSIGHTS INTO REGIONAL DEVELOPMENT:

@IntoInsights

which I used these territorial planning studies to analyze and monitor the social and environmental impacts of projects in the context of their environmental licensing processes. These experiences allowed me to develop some reflections which are detailed in the next sections of this article.

\subsection{Ecological-Economic Zoning}

Zoning for territorial development seeks to show the development potential of natural resources and socio-spatial articulations, as well as showing their environmental and economic weaknesses. In rural areas, zoning of agricultural suitability, agroclimatological suitability, and optimal classes of land use are presented as consolidated methodologies for assessing the occupation potential of a region. Regarding mineral resources, mineral prospecting mappings are also part of these territorial plans for land use.

Based on a broader understanding of public policies for the territory, ecological-economic zoning (EEZ) is an attempt to integrate the aspects of natural, social, and economic resources in a territorial proposal for sustainable development. This zoning seeks to answer the question of how, through the organization of the space, "to obtain the best results from this process, that is, to maximize social and economic results" (Raimundo Garrido, Secretariat of Water Resources / Ministry of the Environment, Brasil, 2001, p. 178-179). Ronaldo Seroa da Mota (Institute of Applied Economic Research-IPEA—, Brazil, 2001, p. 99) stresses the importance of an instrument such as the EEZ, as an integrator between economics and ecology, endeavoring to give information to users to analyze whether the socio-environmental cost of a given use of natural resources is greater or less than its benefits.

In the State of Minas Gerais, experience with EEZ (MINAS GERAIS, 2007a) showed how areas with greater fragility of natural resources (for example with scarcity of water resources, fragile soils, steep sloping relief) often coincide with areas that historically have lower economic development, and social development problems. The maps of environmental vulnerability and social potential in the Minas Gerais EEZ (Figures 1 and 2), show this pattern well, in which the north and northeast of the state present, at the same time, the worst indexes for both maps. In virtue of environmental limitations (such as water scarcity, low soil fertility, greater propensity to erosion or desertification), these areas usually developed uniquely adapted ecosystems with several endemic species, but in fragile ecological relationships of low resilience. Additionally, despite the natural fragility, these areas ended up preserving relatively more of their native ecosystems due to occupation difficulties; whereas the areas with better aptitude for soil occupation and locomotion usually suffered greater impact to their native vegetation throughout history (which can be observed when analyzing the remaining native vegetation in Minas Gerais in Figure 3, similar to the maps in Figures 1 and 2). The simple translocation of conventional public development programs to these regions with the most fragile social and environmental situations, in addition to enhancing environmental damage, may fail in sustainably maintaining economic projects, due to the low capacity to support water resources and soil fertility. 
Make your research more visible, join the Twitter account of INSIGHTS INTO REGIONAL DEVELOPMENT: @IntoInsights

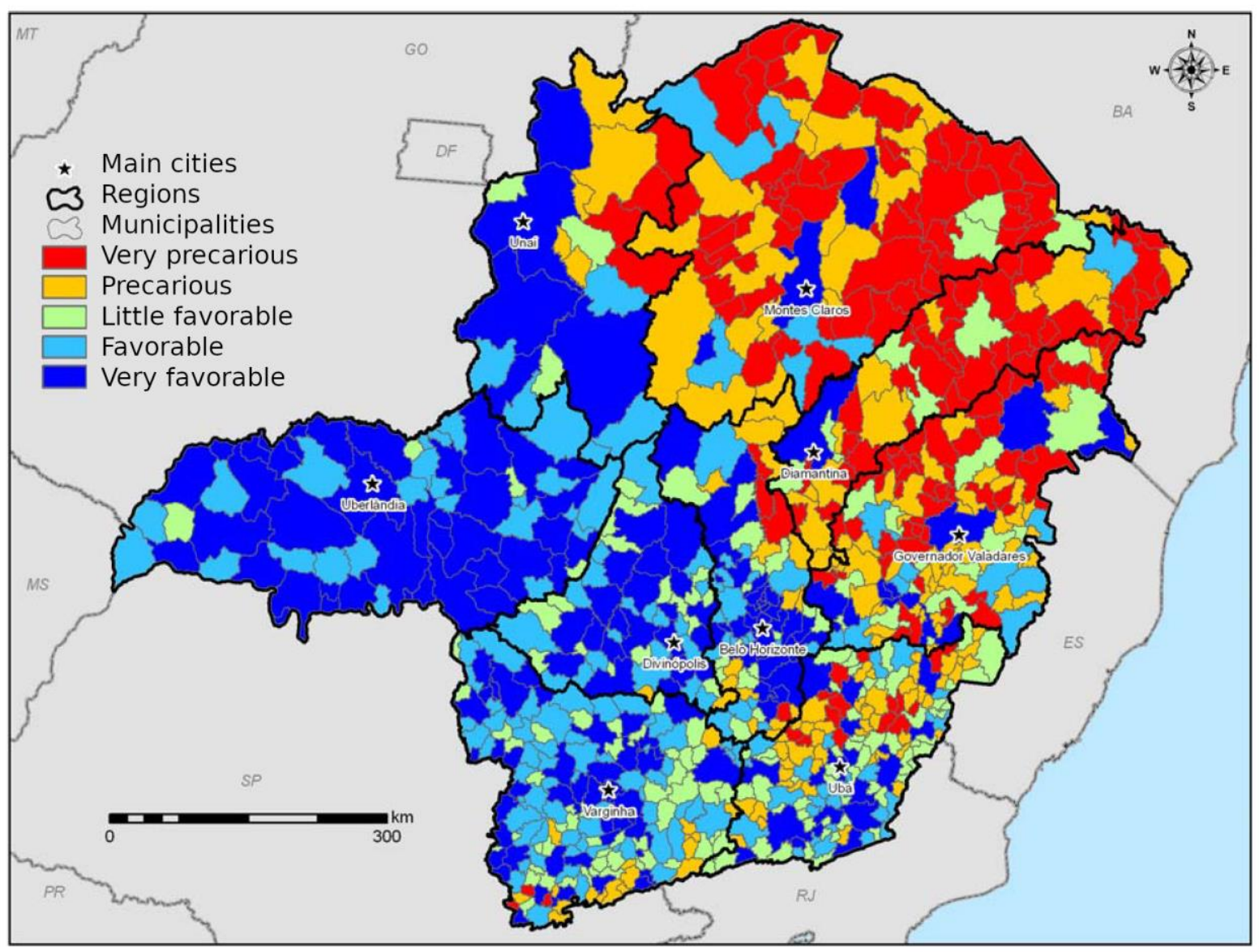

Fig.1. Social potential in the ecological-economic zoning-EEZ —of the State of Minas Gerais.

Source: adapted from Minas Gerais (2007a). 
Make your research more visible, join the Twitter account of INSIGHTS INTO REGIONAL DEVELOPMENT: @IntoInsights

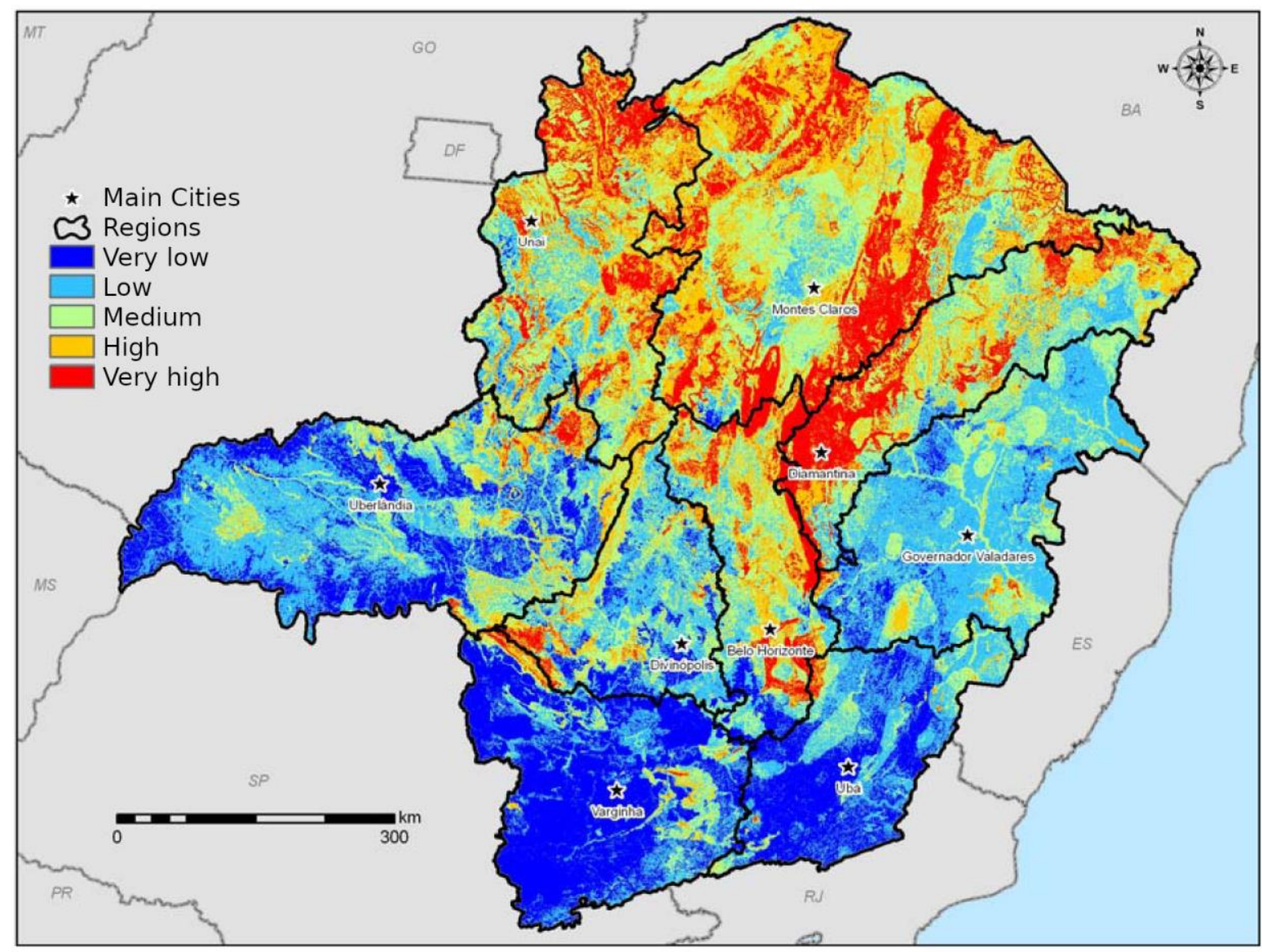

Fig.2. Natural vulnerability in the EEZ of Minas Gerais.

Source: Adapted from Minas Gerais (2007a) 
Make your research more visible, join the Twitter account of INSIGHTS INTO REGIONAL DEVELOPMENT: @IntoInsights

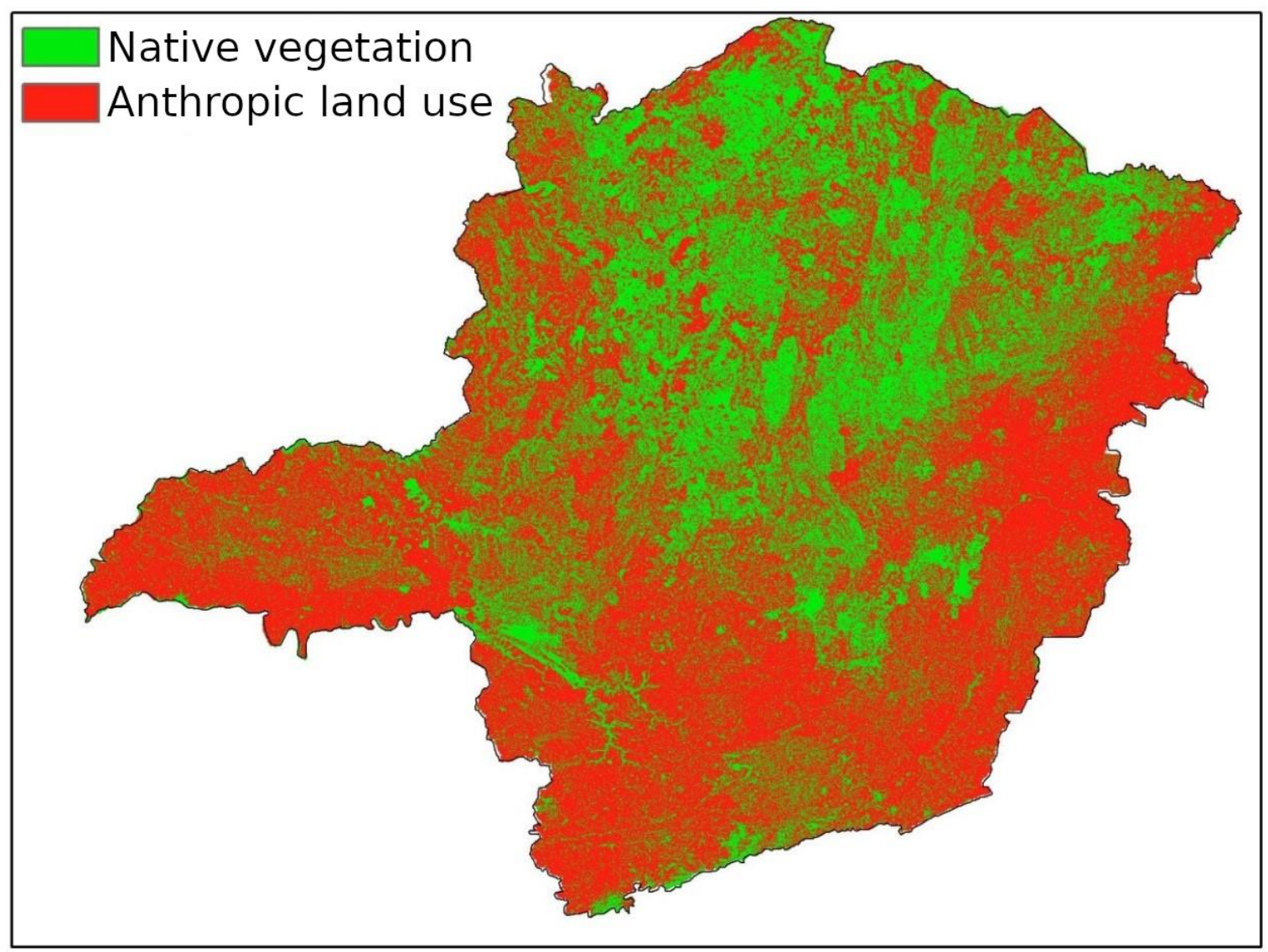

Fig. 3. Native vegetation in the State of Minas Gerais in 2007.

Source: adapted from ALMG (2011), based on data from Carvalho and Scolforo (2008)

In addition to analyzing ecological attributes, it is in the zoning of economic potential - both in the EEZ and other zonings - that the most conflicting issues remain. In a context in which the government is placed in the position of spatially planning the allocation of its scarce resources, it would be appropriate to identify in these plans which investment strategies would bring the greatest social and economic benefit to the population, in short, medium, and long term scenarios. In this context, spatial cost-benefit assessments of investments often show that the economic return on public investments in the most developed areas is greater than the investment in remote areas; as will be discussed in the following section on transport infrastructure. In some way, the economic inequality of territorial development guided by the free market initiative of investors already latently represents the results obtained in these zonings.

These zonings often create tension due to differences in the guidelines in a technical document, and the politicalbudgetary priorities of government decision-makers. There was a widespread perception among technicians from public institutions (such as CETEC-MG, Institute of Applied Geoscience-IGA — and João Pinheiro Foundation) who have prepared territorial planning studies since the time of the military dictatorship in Brazil (1964-1985), that, despite significant financial resources employed to carry out these studies, the final reports would have had 
INSIGHTS INTO REGIONAL DEVELOPMENT

ISSN 2669-0195 (online) http://jssidoi.org/jesi/

2021 Volume 3 Number 1 (March)

http://doi.org/10.9770/IRD.2021.3.1(1)

Make your research more visible, join the Twitter account of INSIGHTS INTO REGIONAL DEVELOPMENT:

@IntoInsights

little influence on the decisions of political leaders and administrative heads responsible for decisions regarding the allocation of public resources.

\subsection{Transport Structure and Regional Implications for Socioeconomic Development}

An interesting experience regarding public planning for regional development was the Strategic Planning for Transport Logistics of Minas Gerais (Minas Gerais, 2007b). The work aimed to provide a spatial perspective of the road network, its transport flows, the degrees of congestion and the conditions of road infrastructure. This data was combined with models for forecasting spatial regional development in Minas Gerais, and how this development tends to increase traffic on the road network. Thus, it was possible to conjecture about the bottlenecks and gaps in road connections, both in relation to the moment of the study and in the form of prognosis. The analyses generated from this information base led to interesting discoveries and conclusions, allowing to observe the trends of traffic congestion and the greater need for maintenance of pavements in the vicinity of large urban centers, as well as the acknowledgement of the importance of the railway network in trade transport, and correlation between economic activities and their raw material and goods transport flows.

Consequently, in the same project, the state government's infrastructure projects portfolio and those projects already provided for by the federal government's Growth Acceleration Program (PAC) were simulated in the database. Aiming for a more informed choice about the priority of resource allocation for projects regarding road and rail networks, a model simulated and mapped the impact of each project on the variables of employment rate, GDP, poverty index, tax collection, and purchasing power, among others. The impact on traditional logistical variables, such as average transport speed, regional cost, and average cost per vehicle was also modeled. This simulation would allow the government to better prioritize and plan transportation infrastructure projects, especially those that would most contribute to accelerating the economic growth of Minas Gerais State.

Nevertheless, the question about the relationship between technical reasoning and political decision could not be hidden. The strategic planning showed that works on transport infrastructure for access to large urban centers would bring greater economic impact. However, due to the political demands of regional development in the marginalized areas of the state, a complementary index was created which showed the potential of infrastructure works to reduce regional inequalities in the state. Not coincidentally, this index was based on inequality between municipalities (it was only spatially based), not taking into account the amount of population in each of the municipalities. Therefore, an index was created to support investment choices that were not necessarily aimed at improving the quality of life of the majority of the population, but rather at creating a less spatially unequal "map" with regard to socioeconomic inequality indices.

A similar logic of regional development was applied in the interstate benefit analysis of these transport projects. The economic models incorporated a greater appreciation of infrastructure projects with development endogenous to the state, reducing the priority of works that would bring greater economic development to the country if these development benefits were mainly directed to other states.

Assessing the transport investment policy of the State of Minas Gerais from attaining strategic planning until 2014, it can be observed that the flagship investment carried out by the state government were the "Minas Pathways (Caminhos de Minas)" and "ProAcesso" programs, with the objective of expanding paved accesses to isolated municipalities. Compared with the strategic planning analyses, the infrastructure projects that would bring more economic development to the state or the country were relegated, due to a political choice of application of resources in marginal areas of the state. This choice was largely reflected by the pressures which 
INSIGHTS INTO REGIONAL DEVELOPMENT

ISSN 2669-0195 (online) http://jssidoi.org/jesi/

2021 Volume 3 Number 1 (March)

http://doi.org/10.9770/IRD.2021.3.1(1)

Make your research more visible, join the Twitter account of INSIGHTS INTO REGIONAL DEVELOPMENT:

@ IntoInsights

deputies and mayors put on the state government, and agreements which they made, so that investment in asphalting in small towns would maintain an alliance of political support for parties in government in subsequent elections. Attention should also be paid to the local effects in small towns that have benefited from paved connections to large urban centers. In the short-term, it drew attention to how the population of the small cities started to make purchases and contract services with the larger urban centers, causing economic disruption to trade and services that previously existed in these small local centers. In the medium term, as paved access made it easier for young people from rural areas to study in larger urban centers, it was common for families to observe that these students generally ended up migrating to the urban center where they studied, justified by the search of better working conditions and quality of life. An analogous phenomenon was also studied by Camargo (2009) regarding the migration of young people to urban centers in the state of Goiás, in Brazil.

These observations raise the hypothesis that paving investments in small municipalities, initially carried out under a regional development discourse, ended up accelerating the trend of concentration of development and population in large urban centers that provide goods, private services, and public services. Such observation is compatible with the econometric models of Domingues et al. (2009), in which investments in infrastructure in Minas Gerais, despite contributing effectively to the economic development of the state, would increase regional inequality. It can be seen that such uneven development, shown in Figure 4, is very consistent with the spatial pattern of social potential for development present in the ZEE-MG, in Figure 2.

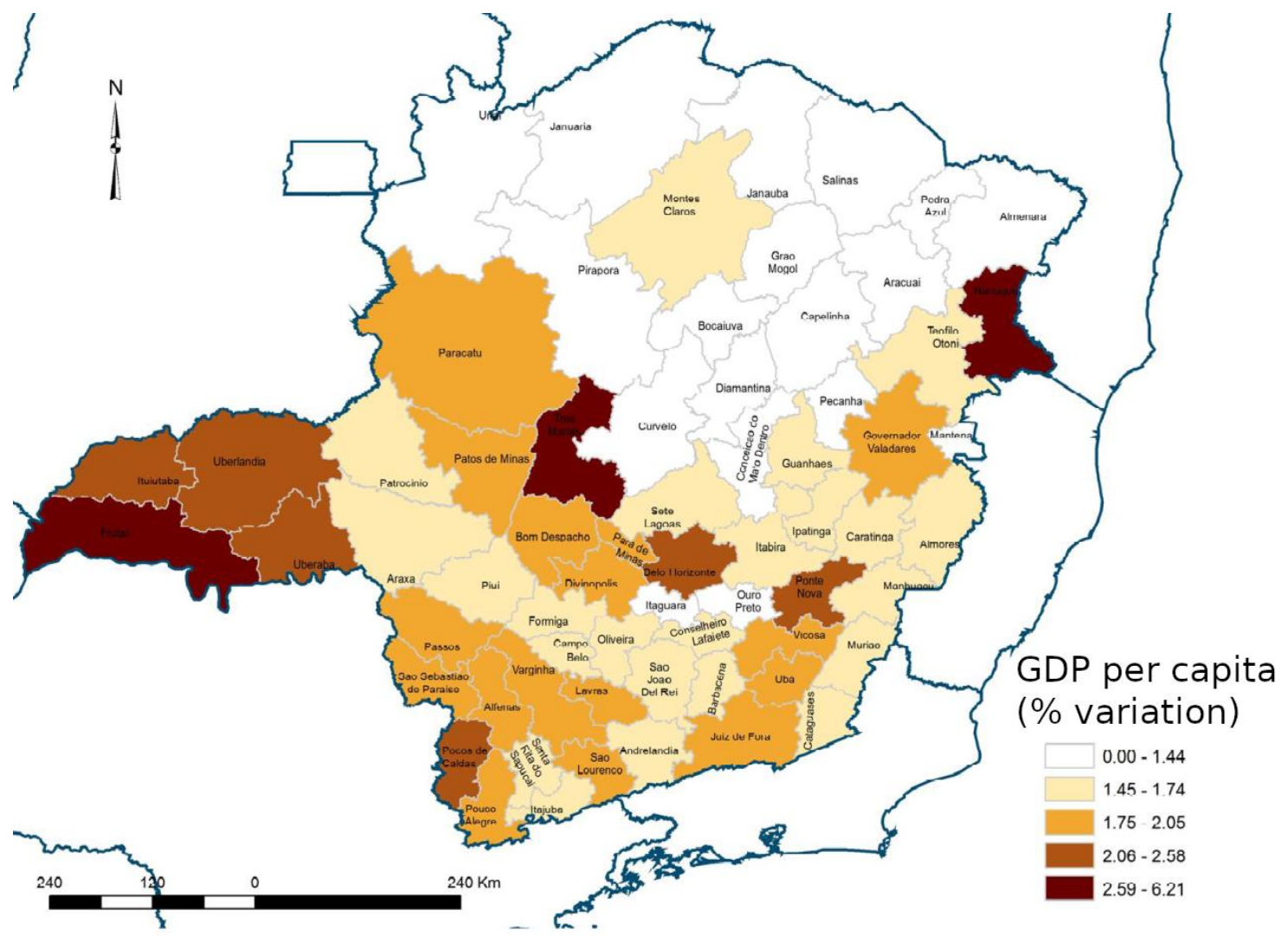

Fig. 4. Long-term impact on GDP per capita due to the infrastructure projects of the Growth Acceleration Plan in Minas Gerais. Source: adapted from Domingues et al. (2009) 
INSIGHTS INTO REGIONAL DEVELOPMENT

ISSN 2669-0195 (online) http://jssidoi.org/jesi/

2021 Volume 3 Number 1 (March)

http://doi.org/10.9770/IRD.2021.3.1(1)

Make your research more visible, join the Twitter account of INSIGHTS INTO REGIONAL DEVELOPMENT:

@IntoInsights

\subsection{City Network Hierarchies}

The theory of medium cities is based on the perspective that with the problems resulting from the swelling of large metropolises, it would be consistent to invest in infrastructure in medium-sized cities, in order to attract the rural exodus to themselves (Amorim; Serra, 2001). This theory originated in post-World War II Europe, and the example of the countries of that continent in generating a social welfare state was taken as a model that could help the Brazilian context.

With a very different approach, Southeast Asian countries, especially China, structured their greatest development into megacities, under the perspective that even with their diverse problems, these large cities would bring greater economic development, and subsequently, improvement in quality of life (Zacharias; Tang, 2010). In the last 20 years of the 21st century, the economic depression and constant crises on the European continent, in contrast to the rapid economic growth and quality of life indicators in China, may lead to rethinking the limits of the development of large urban centers. Perhaps contemporary technological and managerial advances have started to improve the quality of life of the population more rapidly in large urban centers than in medium-sized cities. This hypothesis is consistent with the theory of urban hierarchy in Brazil, from Santos and Silveira (2013), that the social-technological advances and the fading of the rural exodus would lead the intra-urban exodus to concentrate the population more and more in metropolises, while smaller cities would only maintain some size to the extent that it was necessary to provide technical assistance services to more distant agricultural or mining hubs.

However, migrants miss their life in the rural environment or in smaller cities, as shown in studies of human geography based on phenomenology (Ferreira, 2006; Felippe; Kuhnen, 2012). Many of the researchers of theories of regional development and medium-sized cities have as one of their personal motivations the fact that they lived or grew up in small cities. The investigation of whether this personal origin leads to any impartiality in their theories, or whether they enrich them with the wealth of personal experience, is beyond the scope of this text.

Nevertheless, what causes the migrant to leave for the metropolis usually goes beyond the concern of individual feelings, because it is strongly related to their concern with the quality of life of their descendants. Despite the economic, social, cultural, and emotional difficulties faced by migrants, their hope is that their siblings will have a better life than theirs, as they grow up in the metropolis, also well characterized by Menezes (2002). Through similar reasoning, concern for a sustainable development strategy by governments would address the following question: would certain public policies on regional investment, instead of bringing development, be creating yet another generation of descendants who will live in poverty in a depressed region, or is it better to direct more scarce resources to help migrants make the transition to the metropolises, so that the next generation has a more productive life in large urban centers? However, in my professional experience both in the executive and legislative branches, at state and national level, I have constantly observed how those responsible for decisionmaking in the application of public and budgetary policies are more concerned with short-term reasoning. Their first priority is about which option will bring political-electoral credit to maintain the government in the next elections (in a scheme consistent with the theory of public choice (Lessa, 2010)), making it difficult to consider the planning of scenarios in the medium term and, much less, in an intergenerational timespan.

\section{Budgetary Policy and Legislative Power}

In my experience as a legislative consultant for the Legislative Assembly of Minas Gerais (ALMG) from 2010 to 2014, I was able to closely observe the power networks that link electoral strategies to the allocation of the public 


\section{INSIGHTS INTO REGIONAL DEVELOPMENT}

ISSN 2669-0195 (online) http://jssidoi.org/jesi/

2021 Volume 3 Number 1 (March)

http://doi.org/10.9770/IRD.2021.3.1(1)

Make your research more visible, join the Twitter account of INSIGHTS INTO REGIONAL DEVELOPMENT:

@IntoInsights

budget. Paradoxically, in spite of its core competence to make laws, what was observed instead is that the laws with the most significant impact on society were submitted by the State Governor, and were processed with priority and ease, given that the governor's support base was hegemonic within the parliament. Parliamentarians, for the most part, were not dedicated to the bills and relied on the guidance of their advisers and on the executive power. The main focus of the deputies, to whom they almost exclusively dedicated their time and also the human and financial resources of their offices, was to undertake actions for the direct benefit of their electoral base, in order to guarantee these votes for the next election. Among these actions, perhaps the most important was the strategy of applying political influence over the federal and state governments to release financial resources and perform public services for the areas of their electoral bases. Such observation is consistent with the studies by Ames $(1995 \mathrm{a}, \mathrm{b})$ and Pereira and Rennó $(2003$; 2007), which showed that the most important factor for the reelection of a deputy in Brazil would be his ability to direct public resources to his electoral base, which resulted from the good relationship between the deputy and the executive power.

In the state capital of Minas Gerais (Belo Horizonte), even with a large number of voters, electoral competition was higher than in the other municipalities in the state, with an excess of candidates in relation to the number of voters. The electoral base was also more volatile, changing its votes from election to election more easily. This same pattern of greater electoral competitiveness in the capitals in relation to the other interior cities was found in the rest of the country, in the studies Vieira (2012) and Silva (2013).

In the interior regions of Minas Gerais State, contrarily, it was much more common for lasting regional leaders to maintain power, being elected for several consecutive mandates. For the deputies, it became a fundamental strategy to conquer and maintain maximum hegemony in these regions. Such an electoral dispute strategy for spatial hegemony in interior regions was also characterized in the State of São Paulo, in the studies by Avelino et al. (2011) and Braga and Amaral (2013). Vieira (2012), similarly, also showed that deputies from Pernambuco and Rio Grande Sul who had electoral hegemony over a clustered region had higher percentages of reelection than those who had a more dispersed electoral base in their state.

In Minas Gerais, the term "majority region" thus replaced the term "electoral corral" , from the historical origins of Brazilian politics. Also common was the term "making mayors", which meant creating political alliances with local mayors, at the time of the elections, to then favor these mayors with the approval of parliamentary budget amendments or even influencing the distribution of resources by the executive power to those referred municipalities in the structural programs of the state and federal governments.

The essential role of legislative power thus becomes to maintain the political power structure between the federal, state, and municipal executive powers. For the federal and state executive powers, yielding to the pressures to release resources demanded by the deputies becomes the price to pay to maintain the majority support of the parliament and to be able to approve the bills of their authorship (including the annual budget laws). 
INSIGHTS INTO REGIONAL DEVELOPMENT

ISSN 2669-0195 (online) http://jssidoi.org/jesi/

2021 Volume 3 Number 1 (March)

http://doi.org/10.9770/IRD.2021.3.1(1)

Make your research more visible, join the Twitter account of INSIGHTS INTO REGIONAL DEVELOPMENT:

@IntoInsights

The discourse of the reduction of regional inequalities was appropriated by the parliamentarians, in their electoral speeches for their "majority regions". Jacobs et al. (2009), Campello and Zucco (2009), Montero (2010) and Silva (2013) point out that the spatial hegemony of deputies is stronger to the proportion that the regions are poorer, with the lowest level of education and the lowest degree of urbanization. This link between the election of state and federal deputies and the distribution of budgetary resources to the interior regions of the state was quite evident to the population. It was very common to hear on the streets, after public hearings in the countryside, people saying phrases such as "I know that our deputy is corrupt, but if we don't elect him, our region will stop receiving government resources". The risk for a municipality that failed to elect a political representative in the state or federal parliament was that it would be purposefully forgotten by the government regarding the distribution of public resources, especially for infrastructure such as paving roads, and installing and renovating hospitals and schools.

The map in Figure 5, officially published by ALMG (2015), exemplifies these relationships, showing the legal changes for the redistribution of solidary ICMS (tax on the circulation of goods and provision of interstate and intercity transport services and communication) in Minas Gerais, in 2014. The political discourse of the revision of this law called the Robin Hood Act was precisely about the need to redistribute the collected taxes in order to reduce social and regional inequalities. Despite the broad technical support of internal legislative consultancy of ALMG in addition to that given by officers of the State Secretariat for Planning and Management, it must be recognized that the weights and respective results of tax redistribution were ultimately influenced and approved according to the regional political interests of the elected deputies.

The distribution of resources has increased to several (though not all) municipalities with less social potential identified in the EEZ (Figure 1). This distribution has not however taken into account the number of poor people per municipality, and may be questioned regarding all of the controversies relating to sustainable development already discussed in subsections 3.1 to 3.3. Perhaps the most thought-provoking aspect of the map in Figure 5 is that it colors only the municipalities where there has been an increase in the allocation of resources, hiding information about the municipalities that have lost resources (due to the lesser influence on legislative representatives), in a classic example of intentional manipulation of the effects of communication by omitting spatial information. 
Make your research more visible, join the Twitter account of INSIGHTS INTO REGIONAL DEVELOPMENT:

@IntoInsights

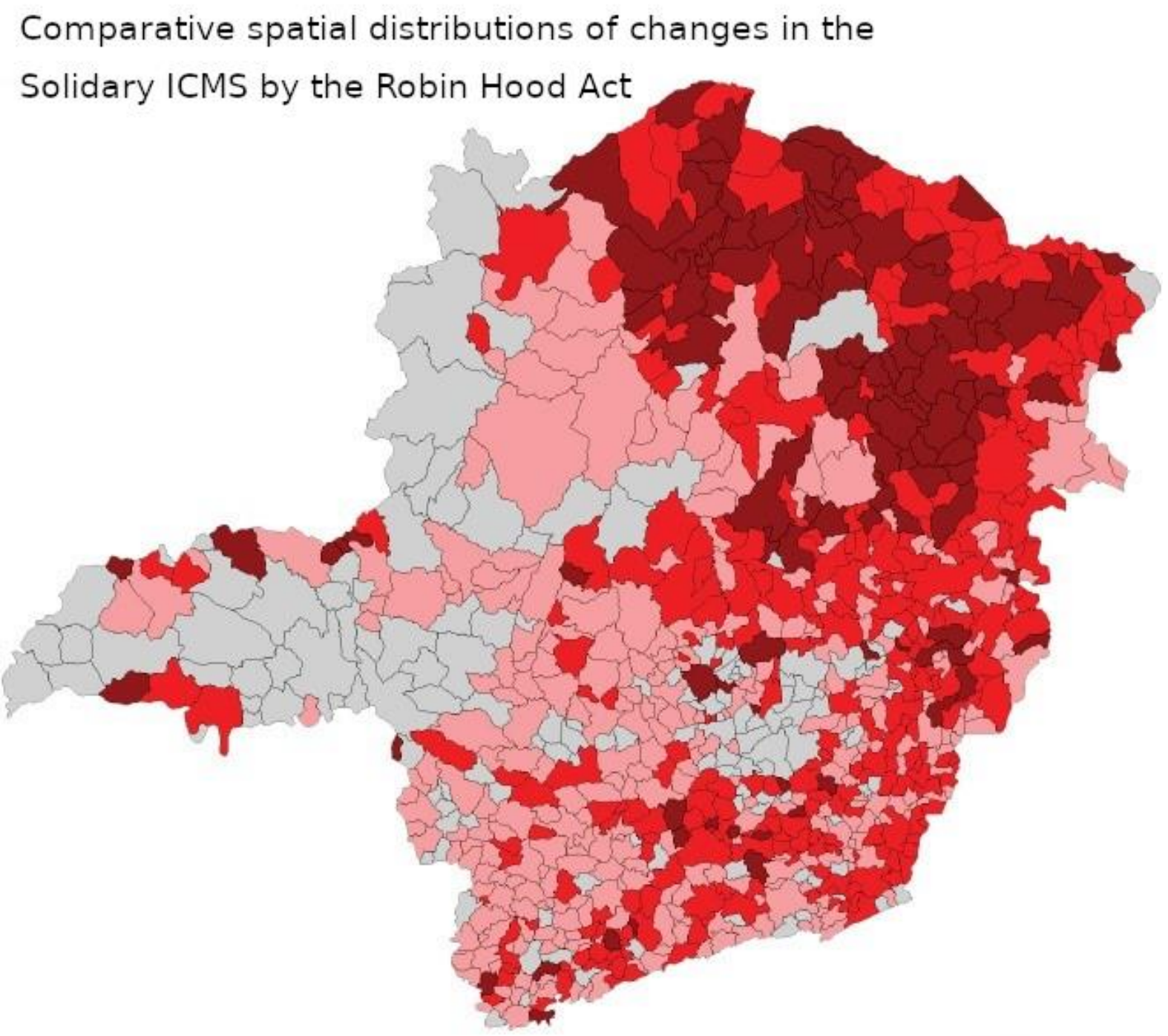

Municipalities that received from $10 \%$ to $50 \%$ more than they would

$\square$ have received in the previous law (108 municipalities)

Municipalities that received from $5 \%$ to $10 \%$ more than they would have received in the previous law (279 municipalities)

Municipalities that received up to $5 \%$ more than they would have received in the previous law (322 municipalities)

Fig. 5. Impact of changes in the redistribution of solidary ICMS in 2015. Source: adapted from ALMG (2015)

These characteristics of the political and budgetary system do not appear to be exclusive to Brazil. During my experience abroad, following the legislative power in Thailand in 2013 and 2014, I was able to observe how the Red Shirt Party (Pheu Thai Party) achieved political hegemony with loyal voters in the countryside, through the 
INSIGHTS INTO REGIONAL DEVELOPMENT

ISSN 2669-0195 (online) http://jssidoi.org/jesi/

2021 Volume 3 Number 1 (March)

http://doi.org/10.9770/IRD.2021.3.1(1)

Make your research more visible, join the Twitter account of INSIGHTS INTO REGIONAL DEVELOPMENT:

@IntoInsights

distribution of resources through local political leaders. This situation was the main reason that led to the protests in 2013 and 2014 of the urban population, in a crisis of political representation of the population in large urban centers. It is the moment when the population realizes that the political scenario becomes a stage for the dispute of interests between the diverse economic and social groups, both regional and national, transforming the democratic system into more a game of influences than a space for dialogue for the common good. In this context, the political crisis therefore consists largely in the perception that representatives are chosen not because the voter agrees with their proposals or their ethical and political values, but because it may bring benefits to their social group or region.

Such a crisis of confidence in political representativeness has also been present in the electorate of Minas Gerais, as well as in the rest of Brazil, according to a study by Baquero and Vasconcelos (2013). Corroborating this thesis, many of the banners and demonstrations observed in the anti-World Cup protests that took place in 2013, in Belo Horizonte and in the main cities of Brazil, also reflected this crisis of representation and confidence of voters in the political class, as documented and analyzed by Cavalcanti ( 2013) and Borja and Caldas (2013).

\section{Final Considerations}

Several studies in critical and human geography strive to demonstrate the socio-spatial marginalization of depressed areas. However, many of these works may have been captured by discourses that cover up strategies for maintaining political power. At stake is also a question of representation of scale: a map showing that a large proportion of investments are in larger cities and not in the smaller cities can be used as a flag of spatial injustice. However, if mapping is carried out on the metropolis scale and it is shown that investments are being channeled to slums and poor neighborhoods, then it is understood that there would be a higher number of inhabitants benefitting.

The most appropriate would be for public investments to be directed to where they could bring greater social and economic development to the population, and not just to aesthetically equalize maps of regional inequality. Spatial inequality can be an ideological banner to cover up strategies for maintaining power, instead of resolving social inequalities. At the same time, zoning that combines economic and social aspects can reveal divergent scenarios with the objectives, discourses, and practices of regional public investment. In this context, it is also necessary to reassess the investment approaches. In depressed areas, with a predominance of a poor rural population, higher investment in education (formal, informal, and extension) may be more efficient and advantageous than using the same public policy schemes employed in other regions with greater economic dynamism. If there is really no productive possibility in the depressed region, investment in education will at least assist in a less difficult transition in case the person or their descendants decide to migrate to an urban center. In addition, there are some lasting questions that are difficult to answer, and an anguish without remedy. Should communities on the fringes of development processes have the right to defend and maintain their lifestyle and work, learned from generation to generation, even when it is no longer economically viable and when their children dream of another type of life? Should they therefore continue their productive model, relying on government aid, while as far as possible providing education so that their children can choose their future, by either following the lives of their parents, or other opportunities? How should a government position itself when proposing an infrastructure project or a new enterprise (or enterprise chain) in the perspective of economic development, but which disturbs these traditional social models? 
INSIGHTS INTO REGIONAL DEVELOPMENT

ISSN 2669-0195 (online) http://jssidoi.org/jesi/

2021 Volume 3 Number 1 (March)

http://doi.org/10.9770/IRD.2021.3.1(1)

Make your research more visible, join the Twitter account of INSIGHTS INTO REGIONAL DEVELOPMENT:

@IntoInsights

The answers are not simple and will not leave decision makers in peace, especially when the allocation of a budgetary resource to a social demand means limiting resources to other social demands that are also pressing. In a conception of society in which constant improvement in quality of life is sought, economic development projects play an essential role and cannot be relegated. However, the cry of the oppressed by these modern cycles of renewal (which always involve destruction in the face of a new recreation) echoes in the bosom of the entire population, and leaves us with this worrying anguish. Could this be a moment when the logic of economic development would give more place to the logic of compassion and solidarity? Beyond the reverberation in the feelings of the citizens, the echo of this cry is also well captured by the strategies of the political representatives and translated in their speeches to maintain electoral bases. Simple speeches that can camouflage complex realities, but in many cases can win votes much more effectively.

\section{References}

Abramovay, R. 2005. "Um novo contrato para a política de assentamentos" [A new contract for the settlements policy], pp. 355-375. in: Oliva, P. M. (org.) Economia Brasileira: Perspectivas do Desenvolvimento [Brazilian economy: perspectives for development]. São Paulo: Ed. CAVC.

ALMG - ASSEMBLEIA LEGISLATIVA DO ESTADO DE MINAS GERAIS. 2011. Fórum Democrático para o Desenvolvimento de Minas Gerais. [Democratic Forum for the Development of Minas Gerais]. Caderno Temático de Meio Ambiente. [Thematic volume on Environment].

ALMG - ASSEMBLEIA LEGISLATIVA DO ESTADO DE MINAS GERAIS. 2015. ICMS Solidário - Avaliação do Impacto da Lei. [Impact Assessment of the Law on Solidary Tax of Goods and Services Operations (ICMS)] Retrieved from http://politicaspublicas.almg.gov.br/export/sites/politicaspublicas/documentos/ICMS/ICMS-Solidario-Flyer.pdf http://www.almg.gov.br/acompanhe/noticias/arquivos/2014/05/27 avaliacao icms solidario.html

Alves, E. 2012. O que falaram os censos do IBGE. [What is informed in the Censuses of the Brazilian Institute of Geography and Statistics (IBGE)] In: Seminário temas estratégicos [Seminar of strategic themes], Brasília. Anais... Brasília: Embrapa Estudos e Capacitação, Retrieved from http://www.fiesp.com.br/arquivo-download/?id=18295

Ames, B. 1995a. Electoral Strategy under Open-List Proportional Representation. American Journal of Political Science, 39(2): 406-433. Retrieved from: https://www.jstor.org/stable/pdf/2111619.pdf

Ames, B. 1995b. Electoral Rules, Constituency Pressures, and Pork Barrel: Bases of Voting in Brazilian Congress. The Journal of Politics, 57(2): 324-343. Retrieved from http://dx.doi.org/10.2307/2960309

Amorim Filho, O., Serra, R. V. 2001. Evolução e perspectivas do papel das cidades médias no planejamento urbano e regional [Evolution and perspectives of the role of medium cities in urban and regional planning]. IPEA. Cidades médias brasileiras [Brazilian medium cities]. Rio de Janeiro: IPEA, 1-34.

Aquino, J.R., Schneider, S. 2010. (Des)caminhos da Política de Crédito do PRONAF, na Luta Contra a Pobreza e Desigualdade Social no Brasil [Paths and deviations of the credit in the Program to strengthen family farming (PRONAF)]. Conferência nacional de politicas públicas contra a pobreza e a desigualdade [National conference on public policies against poverty and inequality], Ed. PPEUR. Natal: UFRN. Retrieved from http://www.cchla.ufrn.br/cnpp/pgs/anais/Artigos\%20REVISADOS/\%28DES\%29CAMINHOS\%20DA\%20POL\%C3\%8DTICA\%20DE\%20CR\%C3\%89DI TO\%20DO \%20PRONAF\%20NA\%20LUTA\%20CONTRA\%20A\%20POBREZA\%20E\%20A\%20DESIGUALDADE\%20SOCIAL\%20NO\%20BRASIL \% 20RURAL.pdf

Avelino, G., Biderman, C., Silva, G. P. 2011. A Concentração eleitoral nas eleições paulistas: medidas e aplicações [Electoral centralization in elections of São Paulo state: measurements and applications]. Dados [Data], 54(1):319-347. http://dx.doi.org/10.1590/S0011-52582011000200004

Baquero, M., Vasconcelos, C. 2013. Crise de representação política, o surgimento da antipolítica e os movimentos apartidarismo no Brasil [Crisis of political representation, the rise of antipolitics and the non-partisan movements in Brazil]. V Congresso da Associação brasileira de pesquisadores em comunicação politica. [V Congress of the Brazilian Association of researchers on political communication] Ed. Compolítica, Curitiba. Retrieved from http://www.compolitica.org/home/wp-content/uploads/2013/05/GT06-Cultura-politica-comportamento-e-opiniao-publica-MarcelloBaquero.pdf 
INSIGHTS INTO REGIONAL DEVELOPMENT

ISSN 2669-0195 (online) http://jssidoi.org/jesi/

2021 Volume 3 Number 1 (March)

http://doi.org/10.9770/IRD.2021.3.1(1)

Make your research more visible, join the Twitter account of INSIGHTS INTO REGIONAL DEVELOPMENT:

@IntoInsights

Belik, W. 2000. PRONAF: avaliação da operacionalização do programa [Policy to strengthen Family farming: evaluation of the operationalization of the program]. O novo rural brasileiro: politicas públicas [The new brazilian rural: public policies], 4: 93-115.

Borja, O.R.P., Caldas, R.W. 2013. Globalização e Desenvolvimento: rumo à nova ordem imperial [Globalization and Development: towards the new imperial order]. Congreso de la asociación latinoamericana de sociología [Congress of the latín-american association of Sociology], 24. Acta científica... 2013. Chile. Asociación Latinomarecana de Sociología. Retrieved from: https://www.semanticscholar.org/paper/Globaliza\%C3\%A7\%C3\%A3o-eDesenvolvimento\%3A-rumo-\%C3\%A0-nova-ordem-Rodrigo-Wahrendorff/7e2b5f4f37705b4598e27670622bc8d40136baa3

Braga, M. D. S. S., Amaral, O. E. 2013. Implicações do processo de seleção de candidatos na competição partidária: o caso brasileiro [Implications of the process of selection of candidates in the partisan competition: the Brazilian case. Sociologia e Politica [Sociology and Politics], 21(46): 33-43. http://dx.doi.org/10.1590/S0104-44782013000200003

Brasil. MMA - Ministério do Meio Ambiente. 2001. Metodologia de Zoneamento Ecológico-Econômico para a Região Sudeste: Transcrição de debates [Methodology of Ecological-Economic Zoning for the Southeast Region: transcription of debates]. Brasília: MMA.

Camargos, A.T. 2009. Jovens Migrantes em Busca de Melhores Condições de Vida [Young migrants in search of better living conditions]. Master Dissertation. $2009 . \quad$ Goiás: Universidade $\quad$ Católica de $\quad$ Goiás. http://tede2.pucgoias.edu.br:8080/bitstream/tede/2207/1/APARECIDA\%20TELES\%20DE\%20CAMARGO.pdf

Campello, D., Zucco, C. 2008. A esquerda em um país democrático, globalizado e desigual: uma análise do Brasil de Lula [The left wing in a democratic, globalized and inequal country: an analysis of the Brazil of Lula], Moreira, C. et al (orgs.). Perspectivas Analiticas Sobre Nuevos Gobiernos y Sociedad en America Latina [Analitic perspectives about the new governments and society in Latin America]. Montevideo: Trilice.

Cardoso, P.P., Swan, A.D. \& Mendes, R. 2018. Exploring the key issues and stakeholders associated with the application of rainwater systems within the Amazon Region. Entrepreneurship and Sustainability Issues, 5(4): 724-735. https://doi.org/10.9770/jesi.2018.5.4(2)

Carvalho, L. M. T., Scolforo, J.R.S. 2008. Inventário Florestal de Minas Gerais: Monitoramento da flora nativa $2005-2007$ [Forest inventory of Minas Gerais: monitoring of native flora]. Lavras: Editora UFLA.

Cavalcanti, V. R. A. 2013. As manifestações de junho de 2013: uma análise a partir do embate teórico entre democracia procedimental e pluralismo agonístico [The demonstrations of June, 2013: an analysis based on the theoretical clash between procedimental democracy and agonistic pluralism]. Monography Universidade de Brasília, Brasília. Accessed July 14, 2020. Retrieved from http://bdm.bce.unb.br/bitstream/10483/7098/1/2013 VictorReisdeAbreuCavalcanti.pdf

Domingues, E. P., Magalhães, A. S., Faria, W. R. 2009. Infraestrutura, crescimento e desigualdade regional: uma projeção dos impactos dos investimentos do Programa de Aceleração do Crescimento (PAC) em Minas Gerais [Infrastructure, growth and regional inequality: a projection of impact of the investiments of the Growth Acceleration Program (PAC) in Minas Gerais]. Pesquisa e Planejamento Economico [Economic Research and Planning], 39(1): 121-158. Retrieved from http://repositorio.ipea.gov.br/bitstream/11058/5125/1/PPE v39_n01_Infraestrutura.pdf

Eiró, F. 2018. Anti-poverty Programs and Vote-Buying Strategies. Kubbe, I. and Engelbert A. (eds), Corruption and Norms, Palgrave Macmillan, Cham, 133-152. https://doi.org/10.1007/978-3-319-66254-1_8

Felippe, M. L., Kuhnen, A. 2012. O apego ao lugar no contexto dos estudos pessoa-ambiente: práticas de pesquisa [The attachment to place in the context of the person-environment studies: research practices]. Estud. psicol. [Psychological Studies], 29(4): 609-617. https://doi.org/10.1590/S0103$\underline{166 \times 2012000400015}$

Ferrari, E. A., Abraão, S. S. "Pronaf Agroecología: sistematización de uma experiencia llevada a cabo en la Zona da Mata de Minas Gerais". [Agroecology in the Program to Strengthen Family Farming (PRONAF): systematization of an experience in Zona da Mata, Minas Gerais] In: Scotto, G. (org.) Aun hay tiempo para el sol. Pobrezas rurales y programas sociales: Brasil, Venezuela, Guatemala. Una mirada desde lo local. 1 ed. Rio de Janeiro: Action Aid Oficina Regional Américas, 2008, v. 1: 65-89. Accessed July 14, 2020. http://oppa.net.br/acervo/publicacoes/Aun_Hay_Tiempo_Para_El_Sol.pdf

Ferreira, K. P. M. 2006. Ficar ou partir?: afetividade e migração de jovens do sertão semi-árido cearense [Stay or leave?: affectivity and migration in young people from the semi-arid hinterland of Ceará]. Master dissertation. Universidade Federal do Ceará, Fortaleza-CE. Retrieved from http://www.repositorio.ufc.br/handle/riufc/2226

Galvanese, C.S. 2018. Paradigmas do planejamento territorial em debate: contribuições críticas a um campo científico emergente [Paradigms of territorial planning in debate: critical contributions to an emerging scientific field]. Doctoral Thesis. São Bernardo do Campo: Universidade Federal do ABC. Retrieved from http://ufabc.net.br/tesepcapes19 
INSIGHTS INTO REGIONAL DEVELOPMENT

ISSN 2669-0195 (online) http://jssidoi.org/jesi/

2021 Volume 3 Number 1 (March)

http://doi.org/10.9770/IRD.2021.3.1(1)

Make your research more visible, join the Twitter account of INSIGHTS INTO REGIONAL DEVELOPMENT:

@IntoInsights

Gazolla, M., Schneider, S. 2005. As duas "caras" do PRONAF: produtivismo ou fortalecimento da produção para autoconsumo? [The two faces of the Program to Strengthen Family Farming (PRONAF): productivism or strengthening the production for self-consumption?] Congresso brasileiro de economia e sociologia rural [Brazilian congress of Rural Economics and Sociology], 43, Proceedings..., Ribeirão Preto/SP: SOBER, 2005.

Guanziroli, C. E. 2006. PRONAF dez anos depois: resultados e perspectivas para o desenvolvimento rural [Ten years of the Program to Strengthen Family Farming (PRONAF): results and perspectives for rural development]. Encontro Nacional de Economia [National meeting of Economics], 34, Salvador (Bahia). Proceedings... Salvador: ANPEC. http://dx.doi.org/10.1590/S0103-20032007000200004

IBGE - Instituto Brasileiro de Geografia e Estatística. 2006. Censo Agropecuário - 2006 [Agricultural census - 2006]. Retrieved from http://www.sidra.ibge.gov.br/bda/acervo/acervo2.asp? $=\mathrm{v} \& \mathrm{p}=\mathrm{CA} \& \mathrm{z}=\mathrm{t} \& \mathrm{o}=3$

Iorio, M., Monni, S., \& Brollo, B. 2018. The Brazilian Amazon: a resource curse or renewed colonialism? Entrepreneurship and Sustainability Issues, 5(3), 438-451. https://doi.org/10.9770/jesi.2018.5.3(2)

Kageyama, A. 2003. Produtividade e renda na agricultura familiar: efeitos do PRONAF-crédito [Productivity and income in Family farming: impact of the credit of the Program to Strengthen Family Farming (PRONAF)]. Agric. São Paulo, SP, 50(2): 1-13. Retrieved from http://www.iea.sp.gov.br/out/publicacoes/pdf/asp-2-03-1.pdf

Lemos, M. (Coord.). 2009. Perspectivas do Investimento na Dimensão Regional [Perspectives of Investiment in the Regional Dimension]. Rio de Janeiro: UFRJ, Instituto de Economia. Retrieved from http://www.projetopib.org/?p=documentos

Lessa, I. L. 2010. Considerações acerca da teoria da escolha pública e o princípio da supremacia do interesse público [Considerations regarding public choice theory and the principle of public interest supremacy]. Cadernos Colaborativos [Collaborative journals]. Fundação Getúlio Vargas. 2010. Retrieved from $\quad$ http://academico.direitorio.fgv.br/wiki/Considera\%C3\%A7\%C3\%B5es acerca da_Teoria da Escolha_P\%C3\%BAblica_e_o_Princ\%C3\%ADpio_da_Supremacia do_Interesse P \%C3\%BAblico

Menezes, M. A. 2002. Redes e enredos nas trilhas dos migrantes: um estudo de familias de camponeses-migrantes [Networks and narratives in the migrants' trails: a study of migrant-peasant families]. Rio de Janeiro: Relume Dumará, 2002.

Minas Gerais. SEMAD - Secretaria de Estado de Meio Ambiente e Desenvolvimento Sustentável. 2007a. Zoneamento Ecológico Econômico do Estado de Minas Gerais [Ecological Economic Zoning of Minas Gerais $\quad$ State]. http://www.meioambiente.mg.gov.br/index.php?option=com_content\&task=view\&id=108

Minas Gerais. SETOP - Secretaria de Estado de Transportes e Obras Públicas. PELT - Plano Estratégico de Logística de Transportes [Strategic Plan of $\begin{array}{llllll}\text { Logistics and } & \text { Transportation } & \text { (PELT)]. } & \text { 2007b. } & \text { Accessed } & \text { July }\end{array}$ http://www.transportes.mg.gov.br/images/documentos/pelt/Plano Estrategico Logistica Transportes.pdf

Monni, S., Iorio, M., \& Realini, A. 2018. Water as freedom in the Brazilian Amazon. Entrepreneurship and Sustainability Issues, 5(4), 812-826. http://doi.org/10.9770/jesi.2018.5.4(8)

Montero, A. P. 2010. No Country for Leftists? Clientelist Continuity and the 2006 Vote in the Brazilian Northeast. Journal of Politics in Latin America, 2(2): 113-153. https://doi.org/10.1177/1866802X1000200205

Muniz, J., da Gloria, M., de Melo, G., Liberato, M., A., R., Wahnfried, I. \& Vieira, G. 2018. Towards sustainability: allowance rights for using water resources in Amazonas State of Brazil. Entrepreneurship and Sustainability Issues, 5(4), 761-779. https://doi.org/10.9770/jesi.2018.5.4(5)

Pereira, C., Rennó, L. 2003. Successful re-election strategies in Brazil: the electoral impact of distinct institutional incentives. Electoral Studies, 22(3): 425448. https://doi.org/10.1016/S0261-3794(01)00057-9

Pereira, C., Rennó, L. 2007. O que é que o reeleito tem? O retorno: o esboço de uma teoria da reeleição no Brasil [What does the re-elected has? The return: outline of a theory of reelection in Brazil]. Brazilian Journal of Political Economy, 27(4): 664-683. http://dx.doi.org/10.1590/S0101-31572007000400010

Potseluev, S. 2010. Dialogue and Quasi-dialogue in the Communicative Theories of Democracy. Rostov-on-Don.

Rocha, G. M., Neves, M. B. 2018. Hydroelectric projects and territorial governance in regions of The State of Pará, Brazilian Amazon. Entrepreneurship and Sustainability Issues, 5(4), 712-723. https://doi.org/10.9770/jesi.2018.5.4(1) 
INSIGHTS INTO REGIONAL DEVELOPMENT

ISSN 2669-0195 (online) http://jssidoi.org/jesi/

2021 Volume 3 Number 1 (March)

http://doi.org/10.9770/IRD.2021.3.1(1)

Make your research more visible, join the Twitter account of INSIGHTS INTO REGIONAL DEVELOPMENT:

@IntoInsights

Santos, M. 2000. Território e Sociedade: entrevista com Milton Santos. [Territory and Society: interview with Milton Santos] 2 ed. São Paulo: Perseu Ábramo.

Santos, M., Silveira, M. L. 2013. Brasil: território e sociedade no início do século XXI [Brazil: territory and society in the beginning of the XXI century]. 17 ed. Rio de Janeiro: Record.

Toledo, E. N. B. 2009. O PRONAF em Salvador das Missões: contradições de uma politica de crédito [The Program to Strengthen Family Farming (PRONAF) in Salvador das Missões: contradictions of a credit policy]. Master Dissertation. Porto Alegre: Universidade Federal do Rio Grande do Sul. Retrieved from https://lume.ufrgs.br/handle/10183/18809

Vasconcelos, V.V. 2011. O Profissional de Meio Ambiente e o Contato com a Natureza [The Environmental Professional and the Touch with Nature], Qualit@s, 11(1): 1-10. http://dx.doi.org/10.18391/qualitas.v11i1

Vasconcelos, V.V., Seingyai, A. 2013. The Songs of the Violated Vereda Wetlands in the Nooks of Brazilian Savannah Backlands, Campo Território, 8(16): 480-508. Retrieved from http://www.seer.ufu.br/index.php/campoterritorio/article/viewFile/20917/13093

Wodak, R.; Rheindorf, M., 2017. Whose Story?, Ikizoglu, D., Wegner, J. and De Fina, A. (eds.) Diversity and super-diversity: sociocultural linguistic perspectives, Georgetown: Georgetown University Press, 17-36.

Zacharias, J.; Tang, Y. 2010. Restructuring and repositioning Shenzhen, China's new mega city, Progress in Planning, 73(4): 209-249. https://doi.org/10.1016/j.progress.2010.01.002

Zucco, C. 2008. The President's 'New' Constituency: Lula and the Pragmatic Vote in Brazil's 2006 Presidential Elections, Journal of Latin American Studies, 40: 29-49. https://doi.org/10.1017/S0022216X07003628

Vitor VIEIRA VASCONCELOS is assistant professor of Ecological Dynamics Applied to Territorial Planning at Federal University of ABC (UFABC). He did a Post-Doc in Stockholm Environment Institute and has a PhD in Natural Sciences with major in Environmental Geology and Conservation of Natural Resources, a PhD stage in Water Engineering, a Master in Geography, a Diploma in Soils and Environment, a Bachelor in Environmental Sciences, a Bachelor in Philosophy, a graduation in Geography Teaching, and two technician degrees in Environment and Industrial Informatics.

ORCID ID: $\underline{\text { https://orcid.org/0000-0002-3063-2776 }}$

Copyright (C) 2021 by author(s) and VsI Entrepreneurship and Sustainability Center

This work is licensed under the Creative Commons Attribution International License (CC BY).

http://creativecommons.org/licenses/by/4.0/

(c) (†) Open Access 